\title{
Staphylococcus capitis isolated from bloodstream infections: a nationwide 3-month survey in 38 neonatal intensive care units
}

Marie Decalonne ${ }^{1} \cdot$ Sandra Dos Santos ${ }^{2} \cdot$ Rémi Gimenes $^{1} \cdot$ Florent Goube $^{1} \cdot$ Géraldine Abadie $^{3} \cdot$ Saïd Aberrane $^{4}$. Vanina Ambrogi ${ }^{5} \cdot$ Raoul Baron $^{6} \cdot$ Patrick Barthelemy $^{7} \cdot$ Isabelle Bauvin $^{8}$. Olivier Belmonte ${ }^{9} \cdot$ Emilie Benabid $^{10}$. Rafik Ben Ammar ${ }^{11}$. Salma Ben Hadj Yahia ${ }^{12}$. Yasmina Berrouane ${ }^{13} \cdot$ Philippe Berthelot $^{14}$. Alain Beuchee ${ }^{15}$. Emmanuelle Bille ${ }^{16}$. Pascal Bolot ${ }^{17}$. Stéphanie Bordes-Couecou ${ }^{18}$. Antoine Bouissou ${ }^{19} \cdot$ Sandra Bourdon $^{20}$. Nadège Bourgeois-Nicolaos ${ }^{21}$ - Sophie Boyer ${ }^{22}$. Christian Cattoen ${ }^{23}$. Vincent Cattoir ${ }^{24}$. Chantal Chaplain ${ }^{25}$. Céline Chatelet ${ }^{26}$ - Aurore Claudinon ${ }^{27}$ - Nathalie Chautemps ${ }^{28} \cdot$ Hélène Cormier $^{29} \cdot$ Céline Coroller-Bec $^{30}$. ${\text { Benjamin } \text { Cotte }^{31} \text { - } \text { Carole De Chillaz }^{32} \text {. Olivier Dauwalder }}^{33} \cdot$ Aude Davy $^{34}$ - Martine Delorme ${ }^{35}$. Maryvonne Demasure ${ }^{36} \cdot$ Luc Desfrere $^{37}$. Michel Drancourt ${ }^{38}$. Clarisse Dupin ${ }^{39}$. Véronique Faraut-Derouin ${ }^{40}$. Arnaud Florentin $^{41}$. Virginie Forget ${ }^{42}$ - Nicolas Fortineau ${ }^{43} \cdot$ Tania Foucan $^{44}$. Pierre Frange ${ }^{16,45}$. Karine Gambarotto ${ }^{46}$. Géraldine Gascoin ${ }^{47}$. Laure Gibert ${ }^{20}$. Jacques Gilquin ${ }^{48}$. Audrey Glanard ${ }^{49}$. Jacqueline Grando ${ }^{50}$. Alain Gravet ${ }^{51}$ • Jérôme Guinard ${ }^{52}$. Geneviève Hery-Arnaud ${ }^{53}$. Claire Huart ${ }^{54}$ • Nadia Idri ${ }^{55,56}$. Jean-Marc Jellimann ${ }^{57}$. Olivier Join-Lambert ${ }^{58} \cdot$ Sylvie Joron $^{59} \cdot$ Philippe Jouvencel $^{60} \cdot$ Marie Kempf $^{61}$. Sophie Ketterer-Martinon ${ }^{62}$. Mouna Khecharem ${ }^{63}$. Serge Klosowski ${ }^{64}$. Franck Labbe $^{65}$. Adeline Lacazette ${ }^{66}$. Fabrice Lapeyre $^{67}$. Jérôme Larche ${ }^{68} \cdot$ Peggy Larroude $^{69}$. Anne Le Pourhiennec ${ }^{70}$. Nolwenn Le Sache ${ }^{71}$. Sylvie Ledru ${ }^{72}$ - Annick Lefebvre ${ }^{73} \cdot$ Clément Legeay $^{29} \cdot$ Florence Lemann $^{74} \cdot$ Claire Lesteven $^{75}$. Marion Levast-Raffin ${ }^{76}$. David Leyssene ${ }^{77} \cdot$ Isabelle Ligi $^{78} \cdot$ Alain Lozniewski $^{79}$. Pierre Lureau ${ }^{80}$. Franck-Olivier Mallaval ${ }^{42} \cdot$ Edith Malpote $^{81}$ - Stéphane Marret ${ }^{82} \cdot$ Pascale Martres $^{83} \cdot$ Guillaume Menard $^{84}$. Laura Menvielle ${ }^{85}$. Laurent Mereghetti ${ }^{86} \cdot$ Véronique Merle $^{87} \cdot$ Pascale Minery $^{88}$. Virginie Morange ${ }^{89}$. Julien Mourdie ${ }^{90}$. Anaelle Muggeo ${ }^{91}$. Jean Nakhleh ${ }^{92}$ - Marie-Noëlle Noulard ${ }^{93}$. Claude Olive ${ }^{94}$ Hugues Patural $^{95}$. Pascale Penn ${ }^{96} \cdot$ Manuel Petitfrere $^{97} \cdot$ Bruno Pozetto $^{98} \cdot$ Brigitte Riviere $^{99} \cdot$ Audrey Robine $^{100}$. Christine Roques Ceschin ${ }^{5}$. Raymond Ruimy ${ }^{101}$ - Amine Siali ${ }^{102} \cdot$ Stéphanie Soive ${ }^{103} \cdot$ Souad Slimani ${ }^{104}$. Anne-Sophie Trentesaux ${ }^{105} \cdot$ Dominique Trivier $^{26} \cdot$ Christian Vandenbussche $^{106} \cdot$ Laurent Villeneuve $^{107}$. Evelyne Werner $^{108} \cdot$ Stéphane Le Vu ${ }^{109} \cdot$ Nathalie Van DerMee-Marquet ${ }^{1,2}$

Received: 13 February 2020 / Accepted: 3 May 2020 / Published online: 9 June 2020

(C) The Author(s) 2020

\begin{abstract}
To increase the knowledge about S. capitis in the neonatal setting, we conducted a nationwide 3-month survey in 38 neonatal intensive care units (NICUs) covering $56.6 \%$ of French NICU beds. We demonstrated $14.2 \%$ of S. capitis BSI (S.capBSI) among nosocomial BSIs. S.capBSI incidence rate was 0.59 per 1000 patient-days. A total of $55.0 \%$ of the S.capBSIs were late onset catheter-related BSIs. The $S$. capitis strains infected preterm babies (median gestational age 26 weeks, median birth weight 855 $\mathrm{g}$ ). They were resistant to methicillin and aminoglycosides and belonged to the NRCS-A clone. Evolution was favorable in all but one case, following vancomycin treatment.
\end{abstract}

Keywords Staphylococcus capitis $\cdot$ NRCS-A clone $\cdot$ Bloodstream catheter-related infection $\cdot$ Neonatal Intensive Care Unit (NICU) $\cdot$ Preterm babies $\cdot$ Neonates $\cdot$ Nationwide active surveillance

Nathalie Van Der Mee-Marquet

n.vandermee@chu-tours.fr

Extended author information available on the last page of the article

\section{Introduction}

Catheter-related bloodstream infections (CRBSI) are associated with increased rates of morbidity in intensive care unit patients and in neonates [1]. The prevention of the avoidable 
part of CRBSIs is a public health priority [2,3]. In this context, since 2019, all French hospitals and clinics are encouraged to participate in an annual 3-month survey of CRBSI coordinated by the national infection control SPIADI network. Over the last two decades, multidrug-resistant Staphylococcus capitis has been increasingly reported as a major agent responsible for CRBSI in preterm babies [4]. Therapeutic failures likely due to heteroresistance to vancomycin in this bacteria [5] and local epidemics have been identified and investigated in NICUs [5-7]. S. capitis seems to be particularly welladapted to the NICU environment, possibly in connection with its ability to produce biofilm $[8,9]$. However, the neonate contamination routes remain obscure. Recent studies performed in distinct parts of the world have demonstrated a single lineage within the $S$. capitis species, named NRCS-A, responsible for invasive neonatal infections worldwide [10, 11]. The mechanisms that have driven the global dissemination of this clone have not yet been elucidated. We report the results of the 3-month nationwide BSI survey conducted during the first quarter of 2019 in the largest series of NICUs located in 38 French hospitals. We present clinical data related to the neonates suffering from BSI, and the incidence rates and major characteristics of the neonatal BSIs. In addition, using molecular methods, we characterized the isolates responsible for S. capitis BSIs to establish whether or not they belong to the NRCS-A clone. We provide new data that increase the knowledge about S. capitis in the current neonatal setting.

\section{Materials and methods}

\section{BSI epidemiological survey method}

Study population Thirty-eight maternity hospitals comprising neonatal intensive beds participated in the study (Fig. 1). The 447 beds surveyed represented $56.6 \%$ of French neonatal intensive beds (https://www.data.gouv.fr/en/datasets/).

Study design The surveillance program involved a 3-month survey of all cases of nosocomial BSI between January 1 and April 30 2019. The survey covered 33,971 intensive care patient-days (PD). Nosocomial BSIs were defined according to international definitions (CDC). The variables studied included clinical data (i.e., sex, gestational age, birth weight, death within 7 days of BSI diagnosis), major characteristics of the BSI such as the portal of entry (skin [primitive cutaneous form or superinfection of a skin breach], lungs, urine, intravascular device, or digestive tract), and for catheterrelated BSI, the time lag between the insertion of the catheter, and the appearance of the clinical signs of the BSI. The BSI incidence rates were calculated per 1000 PD. Ethical approval of the surveillance program was

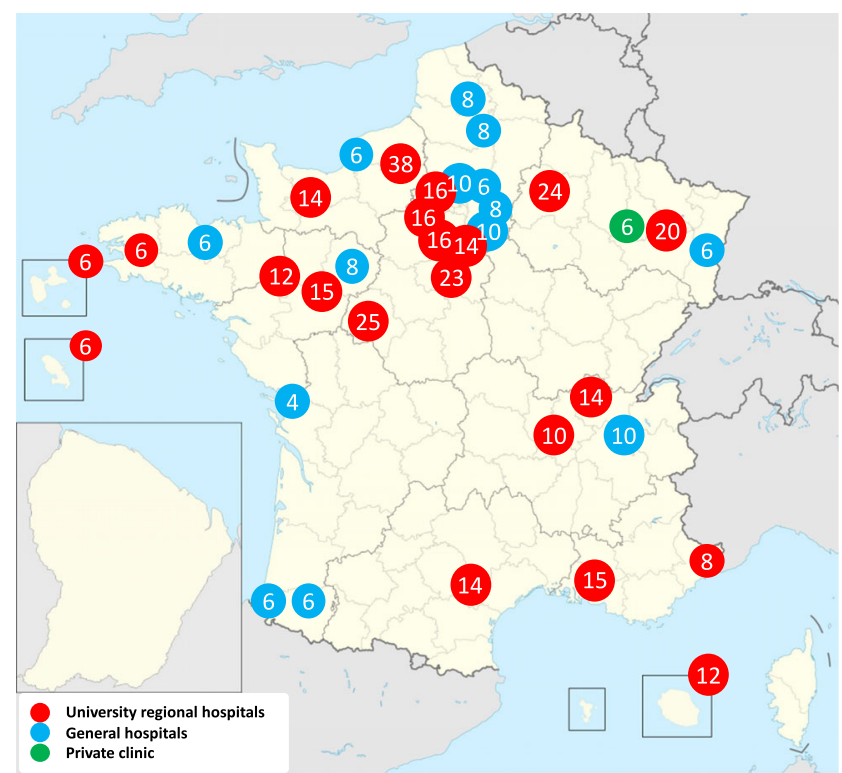

Fig. 1 Location of the 38 participating centers and number of neonatal intensive care beds

obtained at the national level from the Réseau de Prévention des Infections Associées aux Soins.

Microbiological study PFGE was used as a typing technique [12].

Statistical data The data were analyzed with R software. Chisquare tests and Fisher's exact test (two-tailed) were used to test associations, and a $P$ value of 0.05 was considered significant.

\section{Results}

Epidemiology of neonatal BSI During the study period, 141 nosocomial BSIs were diagnosed in 81 male and 60 female neonates. The mean BSI incidence rate was 4.15 per 1000 PD (Table 1). The most frequently isolated micro-organisms were S. epidermidis (39.0\%), S. aureus (17.0\%), S. haemolyticus $(15.6 \%)$, and $S$. capitis $(14.2 \%)$. Twenty BSIs were polymicrobial (14.2\%).

The portal of entry of the BSIs was suspected or proven in $83.7 \%$ of the cases. The digestive tract $(12.1 \%)$, the skin $(8.5 \%)$, and the pulmonary tract (6.4\%) were minor portals of entry. Most of the BSIs were catheter-related (70 CRBSIs; $50.0 \%$ ) (Table 2). The CRBSI involved a central venous catheter (CVC) in 47 cases $(67.1 \%)$, all but one associated with staphylococci $(97.9 \%)$, and an umbilical venous catheter (UVC) in 23 cases $(32.9 \%)$. The UVC-related BSIs were more diverse than those related to CVC: enterococci-, Enterobacteriaceae-, and B. cereus-BSIs 


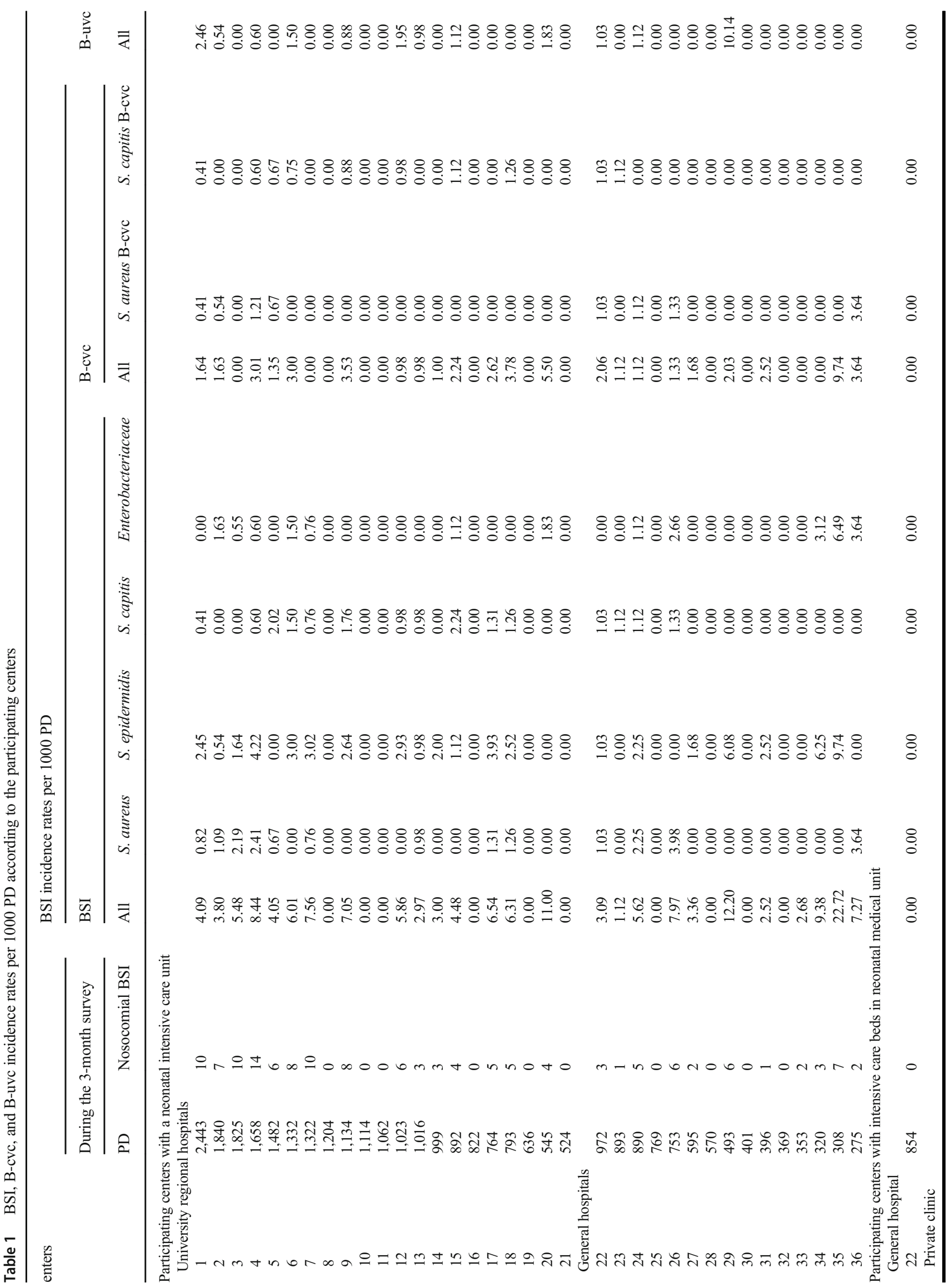



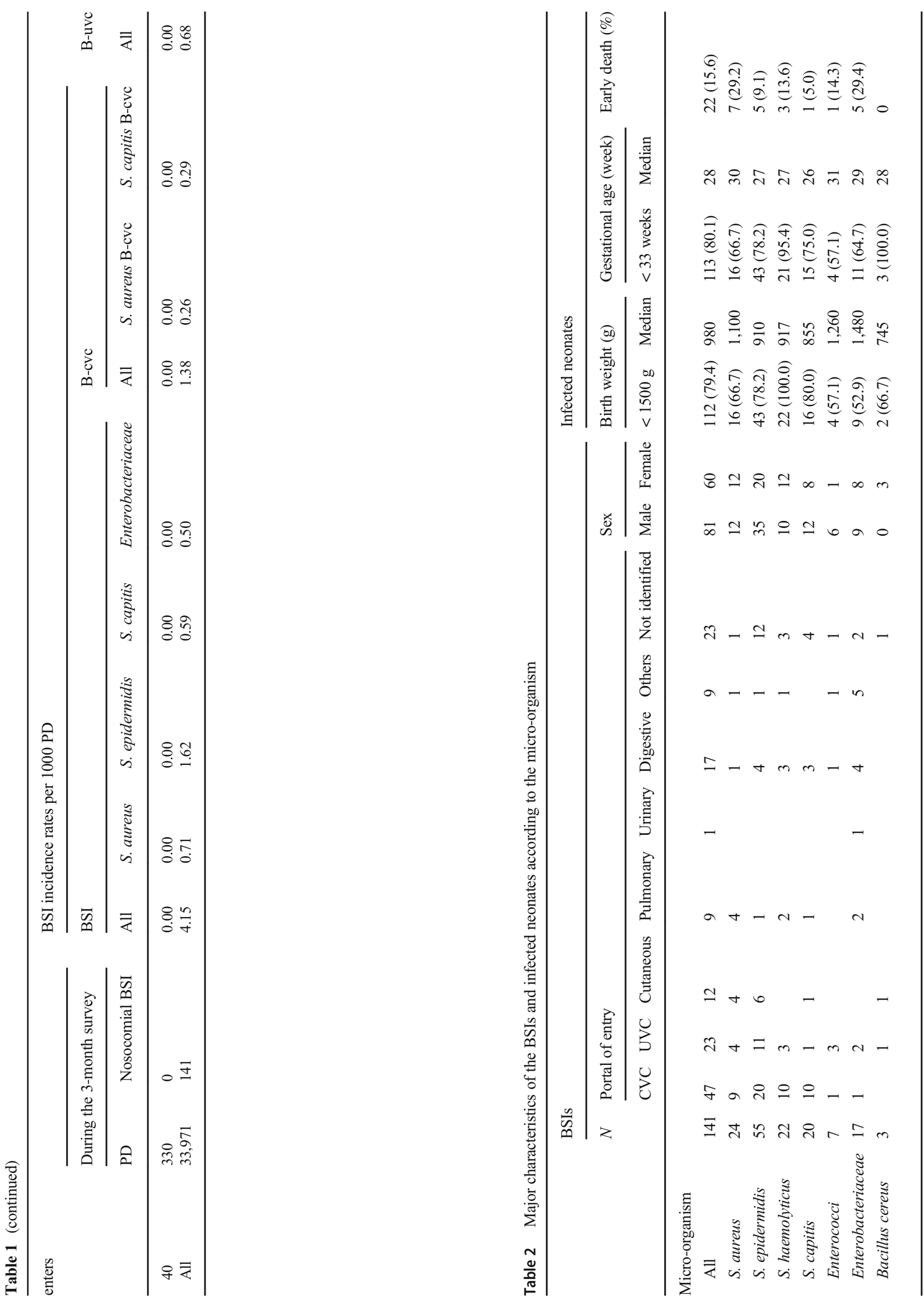
Table 3 Time lag between the insertion of the catheter and the appearance of the clinical signs of the CRBSI

\begin{tabular}{llllll}
\hline & Number of CRBSIs & \multicolumn{2}{l}{ Time lag (days) } & \\
\cline { 3 - 5 } & & Mean & Median & $<10$ days & $\geq 10$ days \\
\hline Micro-organism & 13 & & & & \\
S. aureus & 31 & 7.2 & 6 & 11 & 3 \\
S. epidermidis & 13 & 8.0 & 6 & 26 & 5 \\
S. haemolyticus & 10 & 8.1 & 6 & 9 & 4 \\
S. capitis & 4 & 10.3 & 10 & 4 & 7 \\
Enterococci & 3 & 6.2 & 6 & 4 & 0 \\
Enterobacteriaceae & & 4 & 4 & 3 & 0 \\
\hline
\end{tabular}

were more frequent with UVC-BSIs $(26.1 \%)$ rather than with CVC-BSIs $(4.3 \%)(p=0.022)$. The median time lag between the insertion of the catheter and the appearance of the clinical signs of the BSI was significantly longer for $S$. capitis $(63.6 \%, \geq 10$ days) rather than for $S$. aureus $(7.7 \%)$, S. epidermidis (16.1\%), S. haemolyticus $(30.8 \%)$, enterococci, and Enterobacteriaceae (no case) ( $p=0.018$; Table 3).

Characteristics of the infected neonates The gestational age of the infected neonates ranged between 24 and 41 weeks (median value 28 ), and their birth weight ranged between 455 and $4050 \mathrm{~g}$ (median value 1100 ); $15.6 \%$ of the neonates died during the 7-day period after the diagnosis of the BSI. BSIs involving $S$. aureus, Enterobacteriaceae, and Enterococci were associated with the highest prevalence of early death among infected neonates $(29.4,29.2$, and $14.3 \%$ for Enterobacteriaceae-, S. aureus-, and Enterococci-associated BSIs, respectively). The prevalence of BSI in the neonates with the a gestational age $\geq 33$ weeks and a birth weight $>$ $1500 \mathrm{~g}$ differed according to the bacteria (Table 2): it was the highest for Enterococci (42.9\%), Enterobacteriaceae (35.3\%), and S. aureus (29.2\%), lower for S. capitis $(20.0 \%)$ and E. epidemidis (18.2\%) and nil for S. haemolyticus and B. cereus $(p=0.056)$.

S. capitis BSI characteristics and antibiotic susceptibility of S. capitis strains Twenty BSIs were associated with S. capitis (14.2\%), resulting in a mean incidence of 0.59 per $1000 \mathrm{PD}$, ranging between 0 and 2.24 according to centers
Table 4 Antibiotic susceptibility of the $S$. capitis strains

\begin{tabular}{lllll}
\hline Centers & Strain & Antibiotype* & $\begin{array}{l}\text { MIC vancomycine } \\
(\mathrm{mg} / \mathrm{L})\end{array}$ & $\begin{array}{l}\text { MIC teicoplanine } \\
(\mathrm{mg} / \mathrm{L})\end{array}$ \\
\hline 1 & 1 & Oxa KTG Ri Fu & 0.5 & $<0.25$ \\
9 & 2 & Oxa KTG Ri Fo & 0.5 & $<0.25$ \\
& 3 & Oxa KTG Ri Fo & 0.5 & $<0.25$ \\
4 & 4 & Oxa KTG Ri Fo & - & - \\
7 & 5 & Oxa AKTG Ri Fu Ery & - & 2 \\
13 & 6 & Oxa TG Nor & 1 & $<2$ \\
6 & 7 & Oxa G Cip Ery Ri & $<4$ & $<2$ \\
& 8 & Oxa G Cip Ery & $<4$ & 0.5 \\
5 & 9 & Oxa ATG Ri Fo Te(I) Ery(I) Pr(I) & 1 & 0.5 \\
& 10 & Oxa ATG Ri Fo Te(I) Ery(I) Pr(I) & 1 & 2 \\
15 & 11 & Oxa ATG Ri Fo Te(I) Ery(I) Pr(I) & 1 & 1 \\
& 12 & Oxa ATG Cip Fo & 1 & 1 \\
17 & 13 & Oxa ATG Cip Fo & 1 & 4 \\
12 & 14 & Oxa AKTG Cip Fo & 1 & $<0.25$ \\
22 & 15 & Oxa KTG Ery & 2 & 2 \\
18 & 16 & Oxa AKTG & 0.5 & 0.25 \\
26 & 17 & Oxa ATG Ri Fu & 0.5 & 1 \\
\hline
\end{tabular}

$O x a$ oxacillin, $K$ kanamycin, $T$ tobramycin, $G$ gentamicin, $A$ amikacin, $R i$ Rifampicin, $F u$ fusidic acid, $F o$ fosfomycin, $T e$ tetracyclin, Ery erythromycin, $\operatorname{Pr}$ pristinamycin, Nor norfloxacin, Cip ciprofloxacin 
(Table 1); $39.5 \%$ of the NICUs reported at least one S. capitisBSIs. The $S$. capitis-BSIs were significantly associated with the largest NICUs: at least one $S$. capitis-BSIs was reported in 15 of the 22 NICUs with $\geq 10$ beds, whereas none was reported in the 14 NICUs with $<10$ beds $(p<0.001)$. Four NICUs documented two $(n=3)$ or three $(n=1)$ S. capitis-BSIs during the survey period. The antibiotic susceptibility patterns of 18 strains were available (90.0\%). Most of the strains were resistant to multiple antibiotics, i.e., methicillin (100\%), gentamicin $(100 \%)$, rifampicin $(61.1 \%)$, fosfomycin $(55.5 \%)$, erythromycin (44.4\%), fluoroquinolones (33.3\%), and fusidic acid $(22.2 \%)$. Vancomycin and teicoplanin MIC values ranged between 0.25 and $4 \mathrm{mg} / \mathrm{L}$ (Table 4). Data regarding antibiotic treatment were available for 18 cases: 17 neonates received vancomycin over 2-24 days (median value: 8 days) and the remaining neonate received linezolid (11 days). A favorable outcome was observed in all but one case. An early death was observed for a preterm infected neonate (gestational age 25 weeks; birth weight $455 \mathrm{~g}$ ), who received vancomycin over 3 days following the detection of a $S$. capitis and S. haemolyticus-associated CRBSI.

Twelve S. capitis BSI strains from 8 NICUs were available for molecular typing. A considerable homogeneity was demonstrated among the strains, and PFGE pattern analysis demonstrated that all strains belonged to the NRCS-A clone [10] (Fig. 2). Regarding the three NICUs that reported several $S$. capitis-BSI cases, the strains isolated in a same center shared the same pattern in two cases. In addition, the strains isolated from three distinct centers located in two distant French regions shared the same pattern.

\section{Discussion}

This nationwide study adds several elements to the available data on $S$. capitis responsible for neonatal BSI.

We provide a first mean incidence of $S$. capitis BSIs in French NICUs. S. capitis BSIs currently involve an average of one neonate per $1700 \mathrm{PD}$, which is lower than that observed for $S$. aureus and $S$. epidermidis, but higher than that of Enterobacteriaceae in the population of neonates surveyed. Our findings confirm $S$. capitis as a significant agent responsible for nosocomial BSI in the neonatal setting $[10,11,13]$.

Second, such as S. epidermidis and S. haemolyticus, we showed that $S$. capitis preferentially infects the more fragile neonates and thus confirmed that S. capitis is an opportunistic pathogen, devoid of great virulence potential. Concordant with previous studies [13], all the S. capitis strains responsible for BSIs displayed resistance to methicillin and gentamicin, but remained susceptible to vancomycin. S. capitis-BSIs have been taken into account by the clinicians, and vancomycin probably played a crucial role in the recovery of neonates.

Third, we identified one particularity distinguishing $S$. capitis among the bacteria associated with CRBSI cases. Our study reveals a doubled lag time between insertion of the catheter and the first signs of the BSI involving S. capitis when compared with other bacteria. The absence of early infection likely excludes
Fig. 2 SmaI PFGE patterns of the S. capitis strains responsible for neonatal BSI

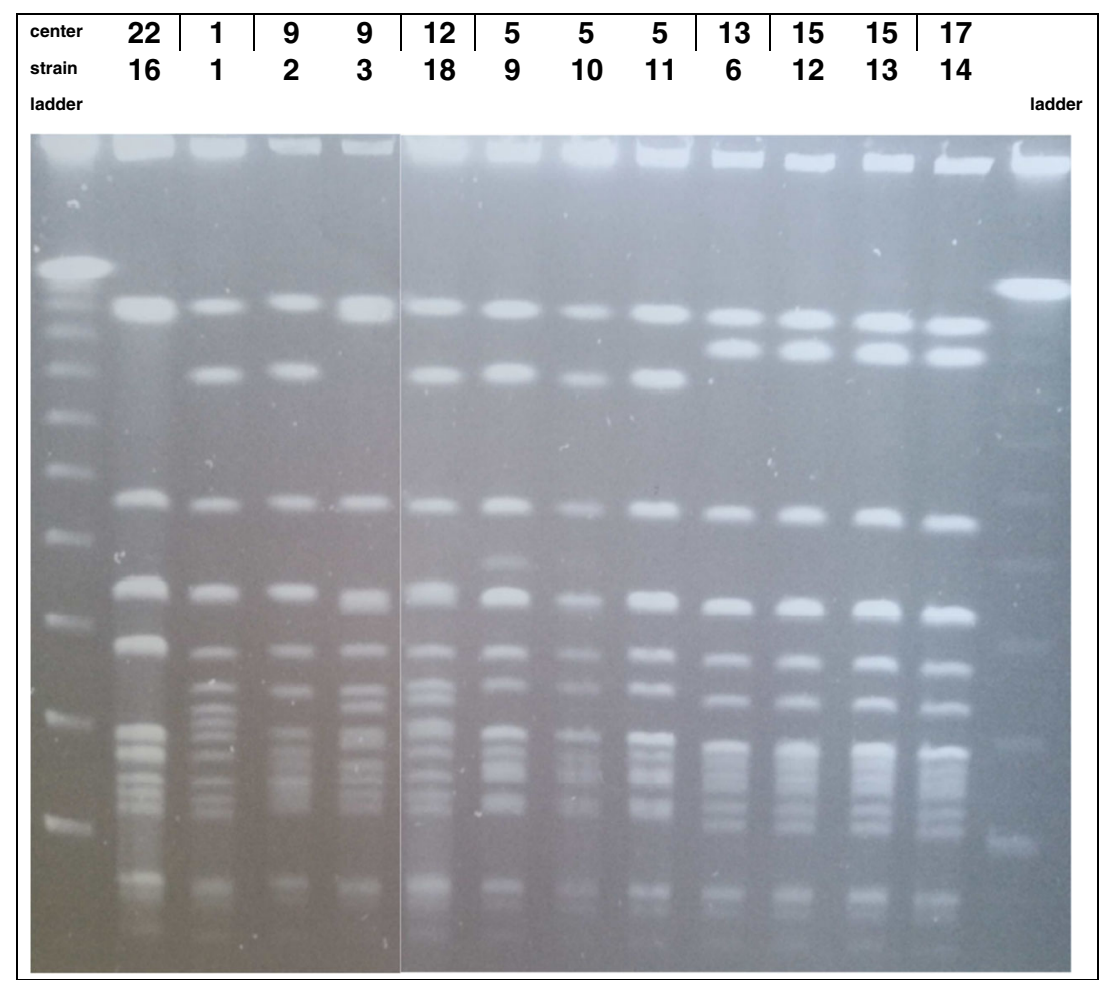


a contamination of the catheter at the time of its insertion, but rather indicates that the contamination of the catheter may have occurred following catheter manipulations among neonates presenting the longest periods of catheterization.

Finally, the molecular analysis of a large part of the $S$. capitis strains indicates that they belong to the multidrugresistant NRCS-A clone and highly suggests likely epidemic phenomena among the NICUs presenting the highest incidence rates of $S$. capitis BSIs.

\section{Conclusion}

Our data confirm the clone NRCS-A particularly well-suited to the neonatal setting and its cumbersome epidemiology $[10,11$, 13]. In most NICUs, $S$. capitis BSIs remain relatively infrequent among neonates, but concern primarily the most fragile ones. In order to better determine the factors involved in the occurrence of these infections, monitoring of BSIs should be continued and complemented by a systematic investigation when several cases are identified over a 3-month period in the same NICU.

Authors' contribution MD conducted the study, SDS performed the molecular typing, RM conducted the statistical analysis, FG designed and developed the website for data collection and analysis, SLV participated with the data analysis, NVDM designed and conducted the study and wrote the manuscript.

All the others are participating members from each of the 41 NICUs (the infection control practitioner, the microbiologist, and the clinician responsible for the NICU). They collected the data and strains.

\section{Compliance with ethical standards}

Conflict of interest The authors declare that they have no conflict of interest.

Ethical approval The nationwide survey was conducted under the control of the national agency Santé Public France and with the authorization by the CNIL (a national committee for data protection). Ethical review and approval was not required for the study on human participants in accordance with the French national legislation and institutional requirements.

Informed consent In each participating hospital, a quality commitment charter was signed by the general director and the infection control physician. Patients were informed and ask for consent about the 3-month national survey.

Open Access This article is licensed under a Creative Commons Attribution 4.0 International License, which permits use, sharing, adaptation, distribution and reproduction in any medium or format, as long as you give appropriate credit to the original author(s) and the source, provide a link to the Creative Commons licence, and indicate if changes were made. The images or other third party material in this article are included in the article's Creative Commons licence, unless indicated otherwise in a credit line to the material. If material is not included in the article's Creative Commons licence and your intended use is not permitted by statutory regulation or exceeds the permitted use, you will need to obtain permission directly from the copyright holder. To view a copy of this licence, visit http://creativecommons.org/licenses/by/4.0/.

\section{References}

1. Umscheid CA, Mitchell MD, Doshi JA, Agarwal R, Williams K, Brennan PJ (2011) Estimating the proportion of healthcareassociated infections that are reasonably preventable and the related mortality and costs. Infect Control Hosp Epidemiol 32(2):101-114

2. Gastmeier P, Geffers C (2006) Prevention of catheter-related bloodstream infections: analysis of studies published between 2002 and 2005. J Hosp Infect 64(4):326-335

3. Schreiber PW, Sax H, Wolfensberger A, Clack L, Kuster SP (2018) The preventable proportion of healthcare-associated infections 2005-2016: Systematic review and meta-analysis. Infect Control Hosp Epidemiol 39(11):1277-1295

4. Laurent F, Butin M (2019) Staphylococcus capitis and NRCS-A clone: the story of an unrecognized pathogen in neonatal intensive care units. Clin Microbiol Infect 25(9):1081-1085

5. van der Zwet WC, Debets-Ossenkopp YJ, Reinders E, Kapi M, Savelkoul PHM, van Elburg RM et al (2002) Nosocomial spread of Staphylococcus capitis strain with heteroresistance to vancomycin in a neonatal intensive care unit. J Clin Microbiol 40:2520-2525

6. De Silva GD, Justice A, Wilkinson AR, Buttery J, Herbert M, Day NP et al (2001) Genetic population structure of coagulase-negative staphylococci associated with carriage and disease in preterm infants. Clin Infect Dis 33:1520-1528

7. Gras-Le Guen C, Fournier S, Andre-Richet B, Caillon J, Chamoux C, Espaze E et al (2007) Almond oil implicated in a Staphylococcus capitis outbreak in a neonatal intensive care unit. J Perinatol 27: 713-717

8. Qu Y, Daley AJ, Istivan TS, Garland SM, Deighton MA (2010) Antibiotic susceptibility of coagulase-negative staphylococci isolated from very low birth weight babies: comprehensive comparisons of bacteria at different stages of biofilm formation. Ann Clin Microbiol Antimicrob 9:16

9. Cui B, Smooker PM, Rouch DA, Daley AJ, Deighton MA (2013) Differences between two clinical Staphylococcus capitis subspecies as revealed by biofilm, antibiotic resistance, and pulsed-field gel electrophoresis profiling. J Clin Microbiol 51(1):9-14

10. Butin M, Rasigade JP, Martins-Simöes P, Meugnier H, Lemriss H, Goering RV et al (2016) Wide geographical dissemination of the multiresistant Staphylococcus capitis NRCS-A clone in neonatal intensive care units. Clin Microbiol Infect 22:46-52

11. Carter GP, Ussher JE, da Silva GD, Baines SL, Heffernan H, Riley TV et al (2018) Genomic analysis of multiresistant Staphylococcus capitis associated with neonatal sepsis. Antimicrob Agents Chemother 62(11). https://doi.org/10.1128/AAC.00898-18

12. Murchan S, Kaufmann ME, Deplano A, de Ryck R, Struelens M, Zinn CE et al (2003) Harmonization of pulsed-field gel electrophoresis protocols for epidemiological typing of strains of methicillinresistant Staphylococcus aureus: a single approach developed by consensus in 10 European laboratories and its application for tracing the spread of related strains. J Clin Microbiol 41:1574-1585

13. Stenmark B, Hellmark B, Söderquist B (2019) Genomic analysis of Staphylococcus capitis isolated from blood cultures in neonates at a neonatal intensive care unit in Sweden. Eur J Clin Microbiol Infect Dis 38(11):2069-2075

Publisher's note Springer Nature remains neutral with regard to jurisdictional claims in published maps and institutional affiliations. 


\section{Affiliations}

Marie Decalonne $^{1}$ - Sandra Dos Santos ${ }^{2} \cdot$ Rémi Gimenes $^{1}$ • Florent Goube $^{1} \cdot$ Géraldine Abadie $^{3} \cdot$ Saïd Aberrane $^{4}$. Vanina Ambrogi ${ }^{5} \cdot$ Raoul Baron $^{6} \cdot$ Patrick Barthelemy $^{7} \cdot$ Isabelle Bauvin $^{8} \cdot$ Olivier Belmonte $^{9} \cdot$ Emilie Benabid $^{10}$. Rafik Ben Ammar ${ }^{11}$. Salma Ben Hadj Yahia ${ }^{12}$. Yasmina Berrouane ${ }^{13} \cdot$ Philippe Berthelot $^{14}$. Alain Beuchee ${ }^{15}$. Emmanuelle Bille ${ }^{16}$. Pascal Bolot ${ }^{17}$. Stéphanie Bordes-Couecou ${ }^{18}$. Antoine Bouissou ${ }^{19} \cdot$ Sandra Bourdon $^{20}$. Nadège Bourgeois-Nicolaos ${ }^{21}$ - Sophie Boyer ${ }^{22}$. Christian Cattoen ${ }^{23}$. Vincent Cattoir ${ }^{24}$. Chantal Chaplain ${ }^{25}$. Céline Chatelet ${ }^{26}$. Aurore Claudinon ${ }^{27} \cdot$ Nathalie Chautemps ${ }^{28} \cdot$ Hélène Cormier $^{29} \cdot$ Céline Coroller-Bec $^{30}$. Benjamin Cotte ${ }^{31}$ - Carole De Chillaz ${ }^{32}$. Olivier Dauwalder ${ }^{33}$. Aude Davy ${ }^{34}$. Martine Delorme ${ }^{35}$.

Maryvonne Demasure ${ }^{36} \cdot$ Luc Desfrere $^{37}$. Michel Drancourt ${ }^{38}$. Clarisse Dupin ${ }^{39}$. Véronique Faraut-Derouin ${ }^{40}$. Arnaud Florentin $^{41}$. Virginie Forget ${ }^{42}$. Nicolas Fortineau ${ }^{43} \cdot$ Tania Foucan $^{44} \cdot$ Pierre Frange $^{16,45}$. Karine Gambarotto ${ }^{46}$. Géraldine Gascoin ${ }^{47}$. Laure Gibert ${ }^{20}$. Jacques Gilquin ${ }^{48}$. Audrey Glanard ${ }^{49}$. Jacqueline Grando ${ }^{50}$. Alain Gravet ${ }^{51}$ • Jérôme Guinard ${ }^{52}$. Geneviève Hery-Arnaud ${ }^{53}$. Claire Huart ${ }^{54}$ - Nadia Idri ${ }^{55,56}$. Jean-Marc Jellimann ${ }^{57}$. Olivier Join-Lambert ${ }^{58}$. Sylvie Joron ${ }^{59} \cdot$ Philippe Jouvencel $^{60}$. Marie Kempf $^{61}$. Sophie Ketterer-Martinon ${ }^{62}$. Mouna Khecharem ${ }^{63}$. Serge Klosowski ${ }^{64} \cdot$ Franck Labbe $^{65}$. Adeline Lacazette ${ }^{66}$. Fabrice Lapeyre $^{67}$. Jérôme Larche ${ }^{68}$. Peggy Larroude ${ }^{69}$. Anne Le Pourhiennec ${ }^{70}$. Nolwenn Le Sache ${ }^{71}$. Sylvie Ledru ${ }^{72} \cdot$ Annick Lefebvre $^{73} \cdot$ Clément Legeay $^{29} \cdot$ Florence Lemann $^{74} \cdot$ Claire Lesteven $^{75}$. Marion Levast-Raffin ${ }^{76}$. David Leyssene ${ }^{77} \cdot$ Isabelle Ligi $^{78}$. Alain Lozniewski ${ }^{79}$. Pierre Lureau ${ }^{80}$. Franck-Olivier Mallaval ${ }^{42} \cdot$ Edith Malpote $^{81} \cdot$ Stéphane Marret $^{82} \cdot$ Pascale Martres $^{83} \cdot$ Guillaume Menard $^{84}$. Laura Menvielle ${ }^{85}$. Laurent Mereghetti ${ }^{86} \cdot$ Véronique Merle $^{87} \cdot$ Pascale Minery $^{88} \cdot$ Virginie Morange $^{89}$. Julien Mourdie ${ }^{90}$. Anaelle Muggeo ${ }^{91}$. Jean Nakhleh ${ }^{92} \cdot$ Marie-Noëlle Noulard $^{93} \cdot$ Claude Olive $^{94} \cdot$ Hugues Patural $^{95}$. Pascale Penn ${ }^{96}$. Manuel Petitfrere ${ }^{97} \cdot$ Bruno Pozetto $^{98} \cdot$ Brigitte Riviere $^{99} \cdot$ Audrey Robine $^{100}$.

Christine Roques Ceschin ${ }^{5}$. Raymond Ruimy ${ }^{101} \cdot$ Amine Siali $^{102} \cdot$ Stéphanie Soive ${ }^{103} \cdot$ Souad Slimani ${ }^{104}$. Anne-Sophie Trentesaux ${ }^{105}$. Dominique Trivier $^{26} \cdot$ Christian Vandenbussche $^{106} \cdot$ Laurent Villeneuve $^{107}$. Evelyne Werner $^{108} \cdot$ Stéphane Le $\mathrm{Vu}^{109} \cdot$ Nathalie Van DerMee-Marquet ${ }^{1,2}$

1 SPIADI, CPIAS CVDL, Hôpital Bretonneau, Centre Hospitalier Universitaire, 37044 Tours, France

2 Cellule d'Epidémiologie Régionale des Infections Nosocomiales, CPIAS CVDL, Service de Bactériologie-Virologie-Hygiène, Hôpital Trousseau, CHRU, 37044 Tours, France

3 Service de réanimation néonatale, Centre Hospitalier Universitaire Félix Guyon, 97400 Saint Denis de la Réunion, France

4 Laboratoire de Microbiologie, Centre Hospitalier Inter-Communal, 94010 Créteil, France

5 Équipe opérationnelle d'hygiène, Centre Hospitalier Universitaire, 31059 Toulouse, France

6 Équipe opérationnelle d'hygiène, Centre Hospitalier Universitaire, 29609 Brest, France

7 Équipe opérationnelle d'hygiène, Hôpital de la Conception, APHM, 13005 Marseille, France

8 Service de réanimation néonatale, Centre Hospitalier, 64000 Pau, France

9 Laboratoire de Microbiologie, Centre Hospitalier Universitaire Félix Guyon, 97400 Saint Denis de la Réunion, France

10 Équipe opérationnelle d'hygiène, Centre Hospitalier, 95300 Pontoise, France

11 Service de réanimation néonatale, Centre Hospitalier Universitaire Antoine-Béclère, APHP, 92140 Clamart, France
12 Laboratoire de Microbiologie, Centre Hospitalier, 62100 Calais, France

13 Équipe opérationnelle d'hygiène, Centre Hospitalier Universitaire, 06200 Nice, France

14 Équipe opérationnelle d'hygiène, Centre Hospitalier Universitaire, 42055 Saint Etienne, France

15 Service de réanimation néonatale, Centre Hospitalier Universitaire, 35000 Rennes, France

16 Laboratoire de Microbiologie clinique, Hôpital universitaire Necker-Enfants malades, APHP, 75015 Paris, France

17 Service de réanimation néonatale, Centre Hospitalier Delafontaine, 93205 Saint Denis, France

18 Équipe opérationnelle d'hygiène, Centre Hospitalier, 64100 Bayonne, France

19 Service de réanimation néonatale, Centre Hospitalier Universitaire, 37044 Tours, France

20 Équipe opérationnelle d'hygiène, Centre Hospitalier du Havre, 76290 Montivilliers, France

21 Laboratoire de Microbiologie, Centre Hospitalier Universitaire Antoine-Béclère, APHP, 92140 Clamart, France

22 Laboratoire de Microbiologie, Centre Hospitalier Universitaire Charles Nicolle, 76000 Rouen, France 
23 Laboratoire de Microbiologie, Centre Hospitalier, 59300 Valenciennes, France

24 Laboratoire de Microbiologie, Centre Hospitalier Universitaire, 35000 Rennes, France

25 Laboratoire de Microbiologie, Centre Hospitalier Delafontaine, 93205 Saint Denis, France

26 Équipe opérationnelle d'hygiène, Centre Hospitalier, 62300 Lens, France

27 Laboratoire de Microbiologie, Centre Hospitalier, 95107 Argenteuil, France

28 Service de réanimation néonatale, Centre Hospitalier Métropole Savoie-Site de Chambéry, 73011 Chambéry, France

29 UPLIN, Centre Hospitalier Universitaire, 49933 Angers, France

30 Équipe opérationnelle d'hygiène, Centre Hospitalier, 72000 Le Mans, France

31 Clinique du Val d'Ouest, 69130 Ecully, France

32 Service de Néonatalogie et Réanimation néonatale, Hôpital universitaire Necker-Enfants malades, APHP, 75015 Paris, France

33 Laboratoire de Microbiologie, Hôpitaux Civils de Lyon, 69677 Bron, France

34 Équipe opérationnelle d'hygiène, Centre Hospitalier, 22000 Saint Brieuc, France

35 Équipe opérationnelle d'hygiène, Centre Hospitalier, 79021 Niort, France

36 Équipe opérationnelle d'hygiène, Centre Hospitalier Régional, 45100 Orléans, France

37 Service de réanimation néonatale, Centre Hospitalier Universitaire, Hôpital Louis-Mourier, APHP, 92700 Colombes, France

38 Laboratoire de Microbiologie, Hôpital de la Conception, APHM, 13005 Marseille, France

39 Laboratoire de Microbiologie, Centre Hospitalier, 22000 Saint Brieuc, France

40 Équipe opérationnelle d'hygiène, Centre Hospitalier Universitaire Antoine-Béclère, APHP, 92140 Clamart, France

41 Service d'hygiène et d'analyses environnementales (SHAE), Hôpitaux de Brabois, 54035 Nancy, France

42 Équipe opérationnelle d'hygiène, Centre Hospitalier Métropole Savoie-Site de Chambéry, 73011 Chambéry, France

43 Équipe opérationnelle d'hygiène, Centre Hospitalier Universitaire, Kremlin Bicêtre, APHP, 94275 Le Kremlin Bicêtre, France

44 Équipe opérationnelle d'hygiène, Centre Hospitalier Universitaire, 97159 Pointe-à-Pitre, France

45 Équipe opérationnelle d'hygiène, Hôpital universitaire NeckerEnfants malades, APHP, 75015 Paris, France
46 Équipe opérationnelle d'hygiène, Centre Hospitalier Universitaire Félix Guyon, 97400 Saint Denis de la Réunion, France

47 Service de réanimation néonatale, Centre Hospitalier Universitaire, 49933 Angers, France

48 Équipe opérationnelle d'hygiène, Centre Hospitalier, 81100 Castres, France

49 Équipe opérationnelle d'hygiène, Centre Hospitalier Delafontaine, 93205 Saint Denis, France

50 Équipe opérationnelle d'hygiène, Hôpitaux Civils de Lyon, 69677 Bron, France

51 Laboratoire de Microbiologie, Centre Hospitalier, 68100 Mulhouse, France

52 Laboratoire de Microbiologie, Centre Hospitalier Régional, 45100 Orléans, France

53 Laboratoire de Microbiologie, Centre Hospitalier Universitaire, 29609 Brest, France

54 Équipe opérationnelle d'hygiène, Centre Hospitalier, 59300 Valenciennes, France

55 Équipe opérationnelle d'hygiène, Hôpital Louis-Mourier, APHP, 92700 Colombes, France

56 Laboratoire de Microbiologie, Hôpital Louis-Mourier, APHP, 92700 Colombes, France

57 Service de réanimation néonatale, Centre Hospitalier Universitaire, Hôpitaux de Brabois, 54035 Nancy, France

58 Laboratoire de Microbiologie, Centre Hospitalier Universitaire, 14000 Caen, France

59 Service d'hygiène, Centre Hospitalier, 62100 Calais, France

60 Service de réanimation néonatale, Centre Hospitalier, 64100 Bayonne, France

61 Laboratoire de Bactériologie-Hygiène Institut de Biologie en Santé, CRCINA Inserm U1232, Université d'Angers, Centre Hospitalier Universitaire, 49933 Angers, France

62 Service de réanimation néonatale et réanimation pédiatrique, Centre Hospitalier Universitaire de Martinique, 97261 Fort de France, France

63 Laboratoire de Bactériologie-Hygiène, Centre Hospitalier Universitaire, Kremlin Bicêtre, APHP, 94275 Le Kremlin Bicêtre, France

64 Service de réanimation néonatale, Centre Hospitalier, 62300 Lens, France

65 Laboratoire de Microbiologie, Centre Hospitalier du Havre, 76290 Montivilliers, France

66 Service de réanimation néonatale, Centre Hospitalier Universitaire, 97159 Pointe-à-Pitre, France

67 Service de réanimation néonatale, Centre Hospitalier, 59300 Valenciennes, France 
68 Polyclinique Saint Roch, 34000 Montpellier, France

69 Équipe opérationnelle d'hygiène, Centre Hospitalier, 64000 Pau, France

70 Service de réanimation néonatale, Centre Hospitalier, 62100 Calais, France

71 Service de réanimation néonatale, Centre Hospitalier Universitaire, Kremlin Bicêtre, APHP, 94275 Le Kremlin Bicêtre, France

72 Laboratoire de Microbiologie, Centre Hospitalier, 62300 Lens, France

73 Équipe opérationnelle d'hygiène, Université de Reims ChampagneArdenne, 51100 Reims, France

74 Équipe opérationnelle d'hygiène, Centre Hospitalier, 95107 Argenteuil, France

75 Équipe opérationnelle d'hygiène, Centre Hospitalier Universitaire, 14000 Caen, France

76 Laboratoire de Biologie Médicale, Centre Hospitalier Métropole Savoie-Site de Chambéry, 73011 Chambéry, France

77 Laboratoire de Microbiologie, Centre Hospitalier, 64100 Bayonne, France

78 Service de réanimation néonatale, Centre Hospitalier Universitaire, Hôpital de la Conception, APHM, 13005 Marseille, France

79 Laboratoire de Microbiologie, Hôpitaux de Brabois, 54035 Nancy, France

80 Laboratoire de Microbiologie, Centre Hospitalier, 79021 Niort, France

81 Laboratoire de Microbiologie, Centre Hospitalier Universitaire, 97159 Pointe-à-Pitre, France

82 Service de réanimation néonatale, Centre Hospitalier Universitaire Charles Nicolle, 76000 Rouen, France

83 Laboratoire de Microbiologie, Centre Hospitalier, 95300 Pontoise, France

84 Équipe opérationnelle d'hygiène, Centre Hospitalier Universitaire, 35000 Rennes, France

85 Service de réanimation néonatale et réanimation pédiatrique, Centre Hospitalier Universitaire, Hôpital Robert Debré, Inserm UMR-S 1250 P3Cell, Université de Reims Champagne-Ardenne, 51100 Reims, France

86 Laboratoire de Microbiologie, Centre Hospitalier Universitaire, 37044 Tours, France

87 Équipe opérationnelle d'hygiène, Centre Hospitalier Universitaire Charles Nicolle, 76000 Rouen, France

88 Équipe opérationnelle d'hygiène, Centre Hospitalier, 68100 Mulhouse, France
89 Équipe opérationnelle d'hygiène, Centre Hospitalier Universitaire, 37044 Tours, France

90 Service de réanimation néonatale, Centre Hospitalier du Havre, 76290 Montivilliers, France

91 Laboratoire de Bactériologie, Université de Reims ChampagneArdenne, 51100 Reims, France

92 Service de réanimation néonatale, Centre Hospitalier, 68100 Mulhouse, France

93 Laboratoire de Microbiologie, Centre Hospitalier, 62000 Arras, France

94 Laboratoire de Microbiologie, Centre Hospitalier Universitaire de Martinique, 97261 Fort de France, France

95 Service de réanimation néonatale, Centre Hospitalier Universitaire, 42055 Saint Etienne, France

96 Laboratoire de Microbiologie, Centre Hospitalier, 72000 Le Mans, France

97 Polyclinique Majorelle, 54000 Nancy, France

98 Laboratoire de Microbiologie, Centre Hospitalier Universitaire, 42055 Saint Etienne, France

99 Laboratoire de Microbiologie, Centre Hospitalier, 81100 Castres, France

100 Service de réanimation néonatale, Centre Hospitalier, 72000 Le Mans, France

101 Laboratoire de Microbiologie, Centre Hospitalier Universitaire, 06200 Nice, France

102 Équipe opérationnelle d'hygiène, Centre Hospitalier InterCommunal, 94010 Créteil, France

103 Service de réanimation néonatale, Centre Hospitalier, 22000 Saint Brieuc, France

104 Équipe opérationnelle d'hygiène, Centre Hospitalier Universitaire de Martinique, 97261 Fort de France, France

Service de réanimation néonatale, Centre Hospitalier Universitaire, 14000 Caen, France

106 Équipe opérationnelle d'hygiène, Centre Hospitalier, 62000 Arras, France

107 Laboratoire de Microbiologie, Centre Hospitalier, 64000 Pau, France

Service de réanimation néonatale, Centre Hospitalier Régional, 45100 Orléans, France 